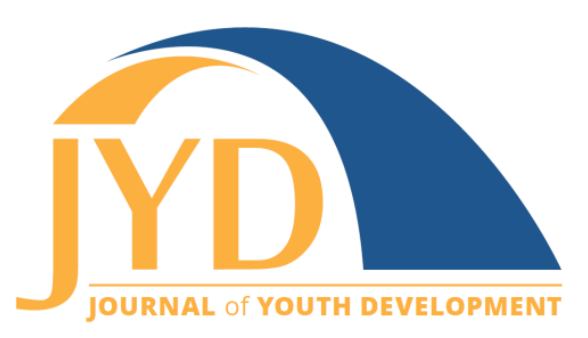

http://jyd. pitt. edu/ | Vol. 14 Issue 3 DOI 10.5195/jyd.2019.883 | ISSN 2325-4017 (online)

\title{
Moving From Risk to Hope: Count Us In
}

\author{
Deborah A. Moroney \\ American Institutes for Research (AIR) \\ dmoroney@air.org
}

\begin{abstract}
In "Moving From Risk to Hope: Count Us In," the author describes the report entitled From a Nation at Risk to a Nation at Hope released in January 2019 by the Aspen Institute National Commission on Social, Emotional, and Academic Development. The report and related brief, Building Partnerships in Support of Where, When, and How Learning Happens offer recommendations for how the education sector can support social and emotional learning and development. This article offers a reflection on the Nation at Hope report recommendations for the youth development field and professionals. There are significant opportunities for the youth development field to partner with other sectors, intentionally support social and emotional learning, train professional staff on strategies to support learning and development, and research our efforts in ways that are accessible and foster practice. It is a critical and hopeful time for the youth development field to honor our history, employ the recommendations in the report, and build our youth development knowledge and practice in light of what we now know about how to optimally foster learning and development.
\end{abstract}

Key words: Nation at Hope, Nation at Risk, youth development, policy, practice, staff development, learning and development, social and emotional learning and development

In January 2019, I sat in the crowded auditorium of a community center in Washington, DC, shoulder-to-shoulder with an entire row of our colleagues, whom I endearingly call the "Who's Who" of the youth development and afterschool fields. We were attending the release of the report $A$ Nation at Hope, and reflecting on the progress we have made since the 1983 work its title refers to: $A$ Nation at Risk. $A$ Nation at Risk was a significant catalyst for action in many sectors, including the youth development field. It is $m y$ hope that this new report serves as another catalyst. The full title of the new report, From a Nation at Risk to a Nation at Hope, embraces the transition from a deficit perspective to a strengths-based lens.

The report was the culmination of a 2-year effort by the Aspen Institute National Commission on Social, Emotional, and Academic Development. The Commission was chaired by education superheroes Linda Darling-Hammond, Chair of the California State Board of Education and CEO

(cc) EY New articles in this journal are licensed under a Creative Commons Attribution 4.0 License. This journal is published by the University Library System, University of Pittsburgh and is cosponsored by the University of Pittsburgh Press. The Journal of Youth Development is the official peer-reviewed publication of the National Association of Extension 4-H Agents and the National AfterSchool Association. 


\section{Moving From Risk to Hope}

of Learning Policy Institute, and Timothy Shriver, Chair and CEO of Special Olympics. Both of these Commission chairs have admirable (and long!) histories as advocates and spokespeople for whole-child education and social and emotional learning. The Commission was also cochaired by then Michigan governor John Engler and later Jorge Benitez, retired Accenture North America CEO-these two co-chairs helped balance the Commission by representing stakeholder groups outside of the education sector.

The Commission included leaders from business, education, the military, parent groups, and research and policy initiatives. From its inception, the charge of the Commission was to focus on "re-envisioning learning to support the whole child" (National Commission on Social, Emotional, \& Academic Development, 2018).

Each of the Commissioners brought a unique perspective from their field or practice. There was one voice clearly representing the youth development field-luckily for us, it was Karen Pittman, CEO and co-founder of the Forum for Youth Investment. In her role on the Commission, Pittman championed a working group of leaders from youth development and afterschool-from big nationals, affiliate organizations, advocacy organizations, and network and intermediary leaders. Commissioner Pittman guided this Youth Development Working Group and ensured that its voice was reflected in the larger Commission's work.

\section{Youth Development Working Group Members}

Afterschool Alliance

Alliance for a Healthier Generation

American Institutes for Research

American Youth Policy Forum

ASCD

BELLXcel

Collaborative for Academic, Social, and

Emotional Learning

City Year, Inc.

Communities in Schools

Connecticut Afterschool Network

Corporation for National and Community

Service

Every Hour Counts

Forum for Youth Investment

FourPoint Education Partners

Girls Inc.

Higher Achievement

\author{
MENTOR-The National Mentoring \\ Partnership \\ National 4-H Council \\ National Afterschool Association \\ National Human Services Assembly \\ National League of Cities \\ National Urban League \\ National Summer Learning Association \\ Playworks \\ Special Olympics \\ Sprockets \\ The 50 State Afterschool Network \\ Trust for America's Health \\ UnidosUS \\ United Way Worldwide \\ Urban Libraries Council \\ WINGS for Kids \\ YMCA of the USA
}

Under Pittman's guidance, the Youth Development Working Group produced the brief Building Partnerships in Support of Where, When, and How Learning Happens. The brief argued that we should expand our thinking about where and when learning happens. It elevated the idea that learning happens both in school and out of school, with families, in communities, in afterschool 


\section{Moving From Risk to Hope}

programs, in the library, at recess, during the summer ... you get it. The brief ultimately informed the main Commission's final set of recommendations, but it also ensured that the youth development field had a voice of its own. I encourage you to read the full brief, but its main recommendations are given here.

\section{Recommendations from the Youth Development Working Group's Building Partnerships in Support of Where, When, and How Learning Happens}

1. Include youth development partners in setting a clear vision.

2. Strengthen and expand adult capacity.

3. Create and support engaging learning settings throughout the day and the year.

4. Provide systems and supports to maintain partnerships.

5. Leverage resources efficiently and equitably.

Perhaps it is because I was a member of the Youth Development Working Group that I am a fan of these recommendations, but to me, this is commonsense guidance for (and from) our field. I hope that these recommendations can guide education professionals and decision makers on the topics we discuss regularly-the discussions we have at staff meetings, at conferences and convenings, and in journals like this one.

In addition to these "little $r$ " recommendations from the brief, there is also a set of six "big R" Recommendations from the Commission. These Recommendations, which are the headliners in A Nation at Hope, were developed by the Commissioners, by the Commission's Council of Distinguished Scientists and Council of Distinguished Educators (I love these noble subcommittee names, don't you?), and by multiple working groups, including the Youth Development Working Group.

I have been reflecting on the six "big R" Recommendations-asking myself how we, the youth development field, fit into them, and how the Youth Development Working Group's recommendations are captured within them. Here's my take. 


\section{Moving From Risk to Hope}

\section{Recommendations from $A$ Nation at Hope}

\section{Set a clear vision that broadens the definition of student success to prioritize the whole child.}

Check! The youth development field, at its core, exists to support the positive development of young people. I think we can confidently say this is our priority. The innovation introduced by the Youth Development Working Group's parallel recommendation "Include youth development partners in setting a clear vision" is that we (the afterschool and youth development fields) should be at the table with educators and other sectors to create a shared cross-sector vision that supports young people in their learning and development.

\section{Transform learning settings so they are safe and supportive for all young people.}

This also seems like a no-brainer for us. In response to (and even prior to) reports like $A$ Nation at Risk, we opened our doors in community centers, faith-based institutions, libraries, cultural centers, and schools to provide a safe and supportive place for young people outside of school hours. Where we can and must improve is in ensuring that all young people have access to safe and supportive settings that foster learning and development. As confirmed by the last America After $3 P M$ survey, there is still significant unmet demand for afterschool and summer programs.

The Youth Development Working Group pushes us a bit further with its similar recommendation to "Create and support engaging learning settings throughout the day and the year." I take their inclusion of the word engaging pretty seriously: It is not enough to offer safe and supportive spaces-we also have to ensure there are opportunities for young people to meaningfully engage with each other, with adults, and with rich learning opportunities. This is critically important, and it ties in with the next Recommendation.

\section{Change instruction to teach students social, emotional, and cognitive skills; embed these skills in academics and schoolwide practices.}

This is a big one, and it's the one most of us think of when we describe social and emotional learning (SEL), character development, enrichment, or other forms of intentional skill building. As a field, we have embraced the concept of social and emotional learning. In 2007, when Durlak and Weissberg released their meta-analysis The Impact of Afterschool Programs that Promote Personal and Social Skills, there was an almost universal exhale in the field-we were 


\section{Moving From Risk to Hope}

validated for what we were doing all along: supporting young people's social and emotional development. It also didn't hurt that, as the era of No Child Left Behind accountability came to an end, we were also validated by the study's findings that select afterschool programs supported academic success to boot. Subsequent field surveys, conversations, and convenings pointed out that youth development practitioners didn't feel prepared to "teach" SEL per se, but did have some promising strategies for "embedding" SEL in other engaging content areas. As a field, we need to bolster this capacity within the youth development workforce and provide intentional strategies for supporting SEL (which leads us to the next Recommendation).

\section{Build adult expertise in child development.}

The Youth Development Working Group had a similar (if a bit more expansive) recommendation: "Strengthen and expand adult capacity." For me-and for us as a field-this is the crux of this work. We hear over and over that relationships are key to learning and development (for example, see the work of the Science of Learning and Development Alliance). We need opportunities for young people that are engaging, that fit where they are in their development and experience ${ }^{1}$, and that are fostered by adults who are equipped with knowledge of child development and with strategies for intentionally teaching and embedding SEL. In the youth development field, we have endeavored to support adult professionals through our intermediary organizations, afterschool affiliates and associations, and state and citywide networks; through resources like standards and competencies; via our busy conference circuit; and through admirable local efforts to provide adult professional learning. Clearly this is a place where we have a foundation to build on, but we need to further focus and expand our efforts. We must focus on how we can professionalize the field, and provide common preparation and guidance for youth development professionals on creating the conditions for learning and development and intentional practices that support learning and development.

${ }^{1}$ For some of the research behind this, check out these publications: Osher, D., Cantor, P., Berg, J., Steyer, L., \& Rose, T. (2018). Drivers of human development: How relationships and context shape learning and development. Applied Developmental Science, doi:10.1080/10888691.2017.1398650; Walker, J., Marczak, M., Blyth, D. \& Borden, L. (2005). Designing youth development programs: Toward a theory of developmental intentionality. In J. L. Mahoney, R. W. Larson, \& J. S. Eccles (Eds.), Organized activities as contexts of development (pp. 399-418). Mahwah, NJ: Erlbaum. 


\section{Moving From Risk to Hope}

\section{Align resources and leverage partners in the community to address the whole child.}

No one really knows why it took so long, but we seem to have finally reached high-level agreement that we need to partner across settings and systems (including shared funding) to support children and youth in their learning and development. Period. This is underlined by the almost parallel Youth Development Working Group recommendation, "Provide systems and supports to maintain partnerships." As the Youth Development Working Group recommendation suggests, we know that partnerships between settings already exist (such as between school and afterschool, between food services and extension programs, and between summer programs and libraries), but these partnerships require resources and systems of support, not to mention time, savvy, and a shared vision (remember Recommendation 1) to succeed. Right now, most of our systems live in silos, and we all need to foster collaboration across sectors and systems to ensure young people have aligned experiences that foster growth and development both within and across settings.

\section{Forge closer connections between research and practice by shifting the paradigm for how research gets done.}

As someone occasionally accused of being a researcher, I particularly love this recommendation, because it doesn't call for more research, but for more applicable, accessible, and equitable research agendas that embrace, learn from, and contribute to practice. I read this one as no more secret research (wasting resources), no more research agendas driving practice, and as a mandate to "work collaboratively and bi-directionally on pressing local problems that have broader implications for the field" (Aspen Institute National Commission on Social, Emotional, \& Academic Development, 2018, Recommendation 6, para. 1).

The final Youth Development Working Group recommendation was to "Leverage resources efficiently and equitably." One could argue that research is a resource, but the Youth Development Working Group was going bigger here, suggesting that the youth development field needs increased and more stable funding to be an equal partner in supporting young people's learning and development. No argument here-and I suggest that funding go, in large part, to practice and the systems that support youth development professionals and the staff members who most directly impact young people in their learning and development. 


\section{Moving From Risk to Hope}

\section{Conclusion}

So, what do we do with this information? First, we should be proud that we had a seat at the table (thanks to our Youth Development Working Group champions) and that our voices were heard. These recommendations, both from the Youth Development Working Group and the Commission as a whole, reflect our shared vision for supporting "anywhere, anytime" learning and development. I should also mention that the Commission was further informed by other committees of researchers, practitioners, funders, youth, and family members, who authored papers, videos, and other resources to guide the Commission and the field. A plethora of resources, including videos, came from this work, and I encourage you to check them out here.

Second, the issue of funding is real and needed. But in the meantime, there are ways we can recognize the good work of the youth development field in implementing the recommendations (both big and small R's) and where we can, start applying the recommendations of A Nation at Hope to our everyday practice.

To start we can:

1. Meet with our K-12 and other community-based partners, share the Nation at Hope and Partnership reports and use these as tools to create a common agenda for young people's learning and development across settings.

2. Bolster staff professional learning to ensure it is inclusive of opportunities to reflect on and build knowledge in child development, developmental fit, and intentional practice strategies for social and emotional learning.

3. Also look at our existing intermediary systems and ensure they are aligned with and providing supports for professionals in their programs on what we now know about learning and development.

4. Create shared research and development (R \&D) agendas that address the most pressing issues in practice, provide real-time information back to inform practice improvements, and build the knowledge base in compelling ways that are accessible to a broad audience!

The sun has set on the Commission, but the charge remains. Check out the resources, share them with your colleagues and stakeholders, and let's work together on these sets of recommendations. The youth development field has a rich history of supporting young people in safe and supportive settings and through meaningful and sometimes even life changing 


\section{Moving From Risk to Hope}

relationships. We bring this to the table. We can also leverage our phenomenal infrastructure of intermediaries poised to (actually set up to) disseminate this great new resource and information and support programs and professionals with the newest knowledge on learning and development. This is more than a start, but we need to commit ourselves to reflecting on what we do well and where we need to grow and partner to most optimally support young people in their learning and development in the many places where they live, play, and learn.

$I^{\prime} m$ in and I am hopeful. Are you with me?

\section{References}

Aspen Institute National Commission on Social, Emotional, \& Academic Development. 2018. From a nation at risk to a nation at hope. Retrieved from http://nationathope.org/wpcontent/uploads/2018_aspen_final-report_full_webversion.pdf 